\title{
LEITURA CRÍTICA DE UMA LITERATURA DRAMÁTICA PARA CRIANÇAS E JOVENS: O CASO D'O MACACO E A VELHA, DE IVO BENDER
}

\author{
Mauro de Araújo Menine Júnior \\ Mestrando em Comunicação e \\ Informação - UFRGS
}

RESUMO: Este trabalho propõe uma leitura crítica da literatura dramática para crianças e jovens produzida no Brasil, em meados dos anos 70, a partir do estudo de caso d'O Macaco e a Velha, de Ivo Bender. Das relações entre o teatro e a literatura, a dramaturgia se configura como o elemento de confluência entre estas formas de expressão artística, portanto, a interpretação está apoiada na construção da linguagem, enquanto assunto literário/dramatúrgico, não cênico, teatral. Com breve contextualização histórica, realiza-se um levantamento e cruzamento das qualidades intrínsecas de sua linguagem, apontando as semelhanças e diferenças em cada período analisado.

PALAVRAS-CHAVE: Literatura dramática infantojuvenil; Teatro; Ivo Bender.

Critical reading of dramatic literature for children and youngsters: the case study of $O$ Macaco $e$ a Velha by Ivo Bender.

ABSTRACT: This work proposes a critical reading of dramatic literature for children and youngsters produced in Brazil, in the middle of the 1970s, from the case study of "O Macaco e a Velha" by Ivo Bender. From the relations between theatre and literature, drama stands at the confluence of those artistic expressions, therefore, the performance is supported by the construction of the language as literature-dramatic matter, non scenic, theatrical. In this way, it carries out its historical contextualization performing a survey and intersection of the intrinsic qualities of the language, bringing forward the similarities and differences of each analyzed period.

KEYWORDS: infant young dramatic literature; theater; Ivo Bender. 


\section{Das inserções de novas cenas dramáticas}

Brasil, anos 70, os palcos do país testemunham o boom do teatro para crianças e jovens. Autores, diretores e educadores questionam os anacronismos da velha dramaturgia/encenação didática, moralista e realista. Os axiomas da concepção pedagógica da arte para a criança dão espaço à imaginação, ao lúdico, à pura fruição estética do espetacular. De repente, o público aflora para dentro dos espaços cênicos e os ditos teatreiros correspondem com uma nova estética, identidade e teatralidade. A diversidade temática, a valorização do rico imaginário do folclore brasileiro, o estímulo à criatividade e participação da criança e a retomada das encenações de formas animadas transformam o conceito de produção/recepção do teatro infanto-juvenil contemporâneo.

Assim, propõe-se a crítica de uma obra que compõe este cenário de mudanças, $O$ Macaco e a Velha (uma trilogia para crianças), de Ivo Bender, que constitui um dos textos mais representativos deste período. Para tanto, o estudo da peça se fundamenta a partir da análise dos elementos de sua composição dramática - ação, espaço, tempo e personagens (Palottini, 1995) -, além de uma interpretação qualitativa da linguagem (Pupo, 1991) e sua adequação (Camarotti, 2005) ao público infanto-juvenil, contextualizando-a no âmbito histórico e estético, para cotejá-la com as tendências de então, a fim de responder a seguinte questão: inovação ou conservação?

A perspectiva adotada é a que compreende o teatro para crianças como a produção de um fenômeno artístico, ou seja, estético. Portanto, realizar-se-á uma interpretação, a partir da leitura de sua linguagem, enquanto assunto literário/dramatúrgico, não cênico, teatral, visto que a literatura dramática consiste em fenômeno invariável para a história da crítica, à vista disso que a encenação passa e a dramaturgia fica; e, por fim, a recusa por uma investigação credora de panoramas pedagógicos do teatro para crianças (escolar/educativo/educação) e suas teorizações.

\section{Dos contextos de velhas e novas dramaturgias.}

Para Margot Berthold (2006, p.1), "o teatro é tão velho quanto a humanidade", porquanto, um fenômeno cultural vinculado aos processos evolutivos das civilizações, vide as origens ritualísticas do "faz-de-conta", que caracteriza os fundamentos de todo jogo dramático, e que se constitui predominante em diversas culturas antigas: o ritual como uma 
prática em que o homem representa a si para se comunicar com o mundo visível e invisível. É a prática de uma celebração entre os integrantes da comunidade, de uma comunhão de formas representativas do mundo que mais tarde evolui para uma linguagem estética complexa.

Ao relacionarem-se os relatos deferidos por Philippe Ariès (1978), quanto às relações sociais, familiares e culturais entre crianças e adultos, onde havia o compartilhamento das experiências, pode-se concluir em uma indiferenciação na recepção das artes cênicas até meados dos séculos XIX e XX, quando se aplica a terminologia infantil para classificar esta determinada categoria social e reverter-se o quadro. A concepção do adulto de uma imprescindível realização do processo de socialização, formação intelectual e ensino de valores ético-morais para a criança constituiu uma importante parcela da produção artística e cultural, leia-se, literária, e, por extensão, teatral, a partir de uma relação pedagógica.

No início do século XX o País não fugiu à regra do além-mar: o teatro infantil ${ }^{1}$ é, antes de tudo, um instrumento pedagógico. A função educativa gerou por consequência o teatro escolar, realizado para e por crianças, entre outras coisas. Os autores e educadores relegaram à estética um papel menor, em detrimento de um protagonismo à pedagogia de condutas, normas e valores morais nessa nova cena criativa de um teatro infantil nacional.

No Brasil, a história de um teatro para crianças é uma constante reconstituição de fragmentos esparsos em rara bibliografia especializada. A pesquisa se ressente de um estudo de fôlego que abarque a grandeza da tarefa de registrar os fatos de uma produção cada vez maior. Ao leitor, a investigação se restringe aos poucos artigos, ensaios e notas introduzidos em meio a outras publicações, sobre temas como literatura ou educação infantil, que acabam por repetir o refrão da falta de uma fortuna crítica de referência.

O marco brasileiro do teatro para crianças é a encenação d'O Casaco Encantado (1948), de Lucia Benedetti, produzida pelos Artistas Unidos, com direção de Graça Mello. É o princípio de uma série de transformações dentro do cenário nacional da produção teatral infantil: denota a passagem do amadorismo das encenações anteriores ao tratamento profissional da peça; significa a mudança de atores em cena, pois agora era o adulto que representava para a criança; consagra-se um estrondoso sucesso comercial, projetando a linguagem nacionalmente, sendo que o texto refuta as lições moralizantes da dramaturgia de então, deixando fluir a pura fantasia, apesar de um leve maniqueísmo que encerra a história. A

\footnotetext{
${ }^{1}$ Em Fernando Lomardo (1994) se encontram referências históricas tanto dos dramaturgos e encenadores do teatro enquanto arte quanto dos autores e educadores de expressão pedagógica, mais especificamente daqueles que orientavam o teatro feito pelas crianças, o que não vem ao caso neste trabalho, em função da deferência à produção infantil de cunho estético. Cf. LOMARDO, Fernando. O que é teatro infantil? São Paulo: Brasiliense, 1994.
} 
premissa de que a criança é o adulto de amanhã modelou as representações da produção teatral, dando-lhe contornos mais moralizantes, educacionais, do que artísticos, estéticos: as lições eram incorporadas ao texto.

Se, em meados de 1950, o simbólico intrínseco à tradição oral dos contos tradicionais é desvirtuado em função de uma simplificação pedagógica do conteúdo e a composição dos textos carecia de conflitos bem estruturados, apresentando enredos pouco desenvolvidos, personagens mal caracterizados e desfechos pobremente resolvidos, os anos 60 começam a diversificar a produção. Às histórias originais se acrescentam o ideário temático dos contos de fadas, as lendas folclóricas ou indígenas e outros gêneros da literatura universal (suspense, ficção científica, policial, etc.). Alguns autores como Oscar von Pfuhl (Dom Chicote Mula Manca e seu Fiel Companheiro Zé Chupança), Jurandyr Pereira (A Menina das Estrelas) e Zuleika Mello (A Formiguinha vai à Lua) representam uma pequena mostra da melhoria dos parâmetros estéticos até então vigentes. Uma das principais características do período é a diluição do discurso moral, com mensagens menos explícitas e abertura à composição de personagens mais combativos às regras e condutas sociais, o que demonstra um universo mais intimista, em que o ser humano é construído através de ações complexas, oriundas de um conflito interno que as justifica. O maniqueísmo reinante se torna relativo, mas a conversão do mal pelo bem permanece como um ponto de esvaziamento qualitativo dos textos. Para Fernando Lomardo (1994) é o princípio de uma identidade dramática nacional, pois a originalidade tende a diversificar os temas, as histórias e os recursos dramatúrgicos.

Nos anos 70, caminha-se a uma estética, identidade e teatralidade autônomas. Os trabalhos de Ilo Krugli (Ventoforte), Vladimir Capella (Pasárgada) e Ana Maria Amaral (O Casulo) são expoentes de uma produção que prima pelo aprofundamento de tendências anteriores como a variedade temática e a valorização do folclore brasileiro que "recupera o elemento popular, a festa e o jogo, o casamento na roça, o bumba-meu-boi, as brincadeiras infantis de rua, mediante cenas despojadas, com pouca cenografia, objetos sugestivos que se transformavam, física ou imaginariamente" (LOMARDO, Op. cit., p.72). A imaginação, o lúdico e o estímulo à criatividade e participação da criança são outras marcas desses anos, além de uma retomada das encenações de formas animadas, praticamente esquecidas desde fins do século XIX. Os textos buscavam um diálogo com seu público, propondo o imaginário popular do folclore como fonte de construção de sentido e interpretação de seu discurso, bem como as criações originais de autores, diretores e educadores que questionavam as premissas antigas em que se concebiam a velha dramaturgia. O teatro-educação e o teatro para crianças 
de intenção pedagógica continuavam como a regra em torno dessas "ilhas" de exceção, indícios de uma inversão de valores que despontavam em perspectiva. Assim, a década de 70 é considerada como um marco para o teatro infanto-juvenil, visto que, em seu contexto surge uma grande afluência de público interessada em uma nova dramaturgia.

\section{Uma dramaturgia fora do eixo}

Ao olhar a historiografia brasileira da dramaturgia infanto-juvenil, vê-se que os contextos eram similares em forma e conteúdo. O teatro para crianças no Rio Grande do Sul reproduz muito das questões ideológicas vinculadas ao tema e à sua história, com raros desvios da conduta moralista.

A trilogia d'O Macaco e a Velha ${ }^{2}$, escrita em 1974, é composta pela peça que dá o título ao tríptico, além d'A invasão das Tiriricas e A Estrelinha Cadente. Muitas montagens, adaptações e citações são realizadas trinta anos depois de sua escrita. Talvez a tradução de uma ampla recepção seja a própria descrição que o autor perfaz sobre a gênese e a temática de sua literatura dramática para crianças:

Era preciso, supunha eu, criar histórias, ou peças de teatro, que partissem desse universo mágico, dentro do qual a criança se movimenta, com o qual a criança sonha e onde seu imaginário está imerso. [...] Para mim, o ideal era fazer as histórias acontecerem num cenário junto da natureza. Nele, bananeiras e espantalhos, macacos e poços d'água falam, estrelas caem do céu e se encontram com as pessoas aqui da terra. [...] Tampouco todas as personagens são fantásticas: as figuras humanas são gente comum que trabalha, costura, cozinha, faz pão e luta para sobreviver (SANTOS, 2003, p. 168).

No universo das peças para crianças de Ivo Bender, o real coexiste com o mágico, e os personagens convivem em um ambiente idealizado de compartilhamento junto à natureza. A sua poesia dramática se constrói sempre a partir de assuntos que versem acerca das relações entre adultos e crianças. $\mathrm{O}$ autor desenvolve os mais variados temas: a fraternidade como premissa da relação entre diferentes; a união harmônica para enfrentar os problemas externos; e o despertar de desejos latentes de afeto através da denúncia social como pano de fundo.

${ }^{2}$ O texto é apresentado como trabalho de conclusão do Curso de Pós-Graduação em Lazer e Recreação pela Pontifícia Universidade Católica do Rio Grande do Sul. Logo, em 1978, é encenada no Teatro Leopoldina, sob a direção de Nara Kaiserman e gravado um LP pela gravadora ISAEC; em 1987, o diretor Robert Driver realiza uma montagem em Indianápolis, Estados Unidos e, neste mesmo ano, é adaptada para o rádio pela difusora alemã Deutsche Welle. No Brasil, a atriz, pesquisadora e professora do Departamento de Arte Dramática da Universidade Federal do Rio Grande do Sul, Mirna Spritzer, trabalha em uma nova adaptação para o Núcleo de Peças Radiofônicas de Porto Alegre, transmitida pela Rádio Cultura FM (107.7 FM). Cf. BENDER, Ivo Cláudio. O Macaco e a Velha (uma trilogia para crianças). Porto Alegre: Mercado Aberto, 1985.

Anuário de Literatura, vol. 14, n. 1, 2009, p. 50 
Portanto, a ideia central de cada parte, como a amizade, a união e a solidariedade sempre servirão de mote para a busca de equilíbrio entre os desejos das crianças e a vontade dos adultos.

A composição de seus textos dramáticos apresenta um tratamento adequado do tema ao imaginário infanto-juvenil, valorizando o popular e o folclore com uma linguagem espontânea, sempre próxima àquela empregada pelas próprias crianças. A ação dramática, enquanto elemento principal da fábula, que ocorre em cena aberta, estabelecida a partir de um conflito de interesses opostos, produz-se e resolve frente ao espectador/leitor, e evita a utilização de recursos narrativos exteriores à cena.

Ao analisar-se a evolução da ação dramática nas três peças, percebe-se que as histórias possuem uma unidade de ação exemplarmente aristotélica sobre questões humanas. Há todo um jogo de relações, revelações e peripécias em função das ações dos personagens, que produzem os acontecimentos cênicos de forma coerente, eficiente e inequívoca, provocando a imaginação, a percepção e a sensibilidade do público, bem como estimulam a reflexão e o senso crítico.

Os personagens são apresentados com intenções, objetivos e vontades claras de concluí-los, sendo que estes mesmos elementos colidem com outros e, assim, gera-se o conflito, a mola propulsora do drama que se desenvolverá até a sua resolução. Esta, por sua vez, restabelece a ordem anteriormente afetada ou produz novos estados.

Em O Macaco e Velha, o interesse do espectador/leitor é logo despertado, pois o conflito se estabelece nos primeiros diálogos e o desenrolar da linha de ação dramática é transparente:

Doninha:

Antes de ir-me para horta semear rabanete, vou tratar do meu café-damanhã. Quer dizer, vou tomar minha batida de banana. [...]

Simão:

Chi... Lá vem a velha Dona Doninha, a dona do bananal. Se ela me descobre, vai ficar uma fera. E para evitar encrenca, vou me esconder por aí. (BENDER, 1985, p. 5)

Com a exposição e o nó da narrativa arranjados, as peripécias desdobram o conflito principal em novas situações ou conflitos secundários, como as armadilhas urdidas entre os protagonistas e o envolvimento de novos personagens que vão compondo a trama e ajudam no desenlace dos fatos:

Doninha:

Este boneco de piche que eu tinha guardado na despensa serve muito bem para prender ladrão atrevido. O macaco Simão vai ter a maior surpresa da Anuário de Literatura, vol. 14, n. 1, 2009, p. 51 
vida. Quando encontrar o boneco pela frente, não vai querer, nunca mais, roubar fruta de ninguém. [...] (Id., 1985, p. 7)

Simão:

Vou até em casa buscar a pele de leão que me serve de tapete na sala. E com essa pele... (Ibid., p. 9)

Depois de muita confusão, nasce uma amizade entre o macaco e a velha e uma nova ordem é estabelecida: a relação fraternal entre a velhinha-vovó e o macaquinho-netinho. A peça é a representação do conflito entre gerações e demonstra a necessidade de um mútuo compreender entre os diferentes para uma melhor convivência.

Com A Invasão das Tiriricas, o elemento urbano, representado pelo Comprador de Água, pretende interferir na paisagem rural de Dona Doninha, Simão e do Poço. Outra vez, o conflito se constitui no primeiro quadro:

O Comprador:

Quero comprar toda a água deste poço, todas águas desta terra, todo regato, qualquer riacho. Sendo água, eu compro.

Doninha:

Nem por ouro nem por prata não lhe vendo minha água. (Ibid., p. 19)

Cria-se uma tensão entre os protagonistas, afinal, o Comprador não se deu por satisfeito e corre-se o risco do Poço morrer de sede. À noite, o Comprador planta sementes de tiriricas tinhosas em volta da boca do poço para afastar a velha e o macaco. Mais confusão é armada, e surgem outros conflitos e personagens secundários, como a Lua saudosa de seu amor, o Sol.

Tudo é resolvido com uma reviravolta, e a união entre Simão e Dona Doninha neutraliza e expulsa o "estrangeiro". A harmonia é retomada, todavia, não há alteração no estado das coisas, bem ao contrário da peça anterior que gerava uma nova situação a partir do nascimento da amizade como síntese de resolução dos conflitos. Percebe-se a evolução da relação entre o macaco-menino e a velha-avó da primeira à segunda parte. Agora, estão unidos pela defesa do bem-comum contra interferências externas negativas.

N'A Estrelinha Cadente, a premissa é a mesma, a exposição, o nó e o conflito se concentram nas primeiras falas, prendendo a atenção do espectador/leitor e colocando-o dentro da narrativa:

A Estrelinha:

Socorro! Socorro! Por favor, alguém nesta floreta conhece um bom esconderijo para a gente se esconder? Preciso me proteger do dono do circo que quer me trancar no fundo de uma jaula. (Ibid., p. 31) 
A estrelinha Áurea consegue se esconder, mas logo aparecem o Dono do Circo e Simão, que é surrado por aquele pela sua "má-educação": além de pisar em seu pé, é irascível ao lhe negar maiores detalhes de sua vida. É quando, ao lado da idéia nuclear de denúncia social, um novo assunto se insere na história: o despertar do afeto na criança. $O$ espírito solidário da estrelinha-menina faz com que a mesma se exponha na defesa do macaquinhomenino, sentimento este que é recíproco:

A Estrelinha:

(Sai de seu esconderijo) Pela luz da lua, não posso deixar esse menino levar uma surra. (Recolhe um galinho seco e bate no Dono do Circo que desmaia). (Ibid., p. 34) [...]

Simão:

Estrelinha Áurea. Ela caiu, uma noite dessas, porque tropeçou numa nuvem esburacada. Coitadinha, parecia tão apavorada. (Ibid., p. 32)

A comiseração evolui para um desejo amoroso/sexual não explícito no texto, todavia, ao mesmo tempo em que surge o afloramento das emoções, tem-se a vivência dos percalços da vida que, muitas vezes, impedem a plena realização das vontades. É o que acontece com o desfecho da peça, quando, na clareira da floresta, os personagens se despedem de Áurea:

Doninha:

[...] Que horas você vai ter que partir?

A Estrelinha:

À meia-noite em ponto, a lua cheia vai me mandar uma escada. [...]

A Estrelinha:

Também não gosto de despedidas. (para Simão) Não fica assim, macaquinho.

A Estrelinha:

[...] Muito obrigado por tudo que fizeram por mim, pela amizade e pela liberdade que me devolveram. Até um dia (sobe). [...]

Doninha:

Agora vamos para casa, Simão. A estrelinha já subiu e a noite já vai alta. Amanhã é dia de fazer pão e temos de voltar aqui para buscar lenha.

Simão:

Ai, que saudade da estrelinha cadente! (Ibid., p. 38)

Neste momento de tristeza para Simão, as palavras de Dona Doninha procuram consolar e transmitir tranquilidade, desviando sua atenção do que aconteceu. Isto nada mais é do que demonstrar que a vida continua apesar das vicissitudes do cotidiano. Em meio a um 
assunto sobre exploração do trabalho infantil, como a fala do Dono do Circo exemplifica, “agora você [Áurea] está presa para sempre [iluminar com sua luz o circo]” (Ibid., p. 33), existe espaço para a abordagem de temas delicados, de introduzir uma fala que contemple as diferentes emoções latentes na criança, como o amor e a amizade.

Da análise da ação dramática chega-se ao estudo dos personagens, visto que o Macaco Simão e Dona Doninha dão unidade à trilogia: as ações e conflitos, caracterizações de outras personas e sua função dramática dentro do texto se concatenam em torno de ambos. A fábula se organiza a partir dessa dupla protagonização que, mesmo em lados opostos $(O$ Macaco e a Velha) ou não (A Invasão das Tiriricas e A Estrelinha Cadente), constituem-se como módulo central do drama. O leitor percebe a atuação de todos os personagens em um ambiente fantasioso, relacionando-se como seres humanos com muita naturalidade. O Macaco Simão, o Boneco de Piche, o Poço, a Lua, as Tiriricas e a Estrelinha Cadente são antropomorfizados, possuindo cada um características identificáveis com qualidades humanas: a inteligência, a coragem, a solidariedade, a paciência, a "molecagem" e a meiguice. Este recurso é uma ferramenta que possibilita a aproximação do mundo dos animais e objetos com o humano; é uma estratégia que funciona para além do reconhecimento, pois é fonte de efeitos cômicos e dramáticos por analogia, fazendo com que a criança veja reproduzida a própria lógica de seus hábitos e pensamentos transpostos para outro universo. É a projeção do real no maravilhoso.

Além dos personagens, todos os elementos que compõem o espaço da ação são considerados como seres antropomorfos, embora não respondam ou participem ativamente do seu desenrolar. Por exemplo, quando Dona Doninha celebra alegremente seu dia de trabalho, cumprimentando o sol, o galo e o próprio dia, ou quando o macaquinho faz o mesmo, no interior do Bananal, com um passarinho e o próprio bananal, tem-se essa naturalização das relações.

Os personagens são caracterizados como representações simbólicas do relacionamento entre adultos e crianças, ou seja, do choque permanente entre dois domínios, familiar ou não, e tal aspecto revela a verdadeira face da dramaturgia infanto-juvenil de Ivo Bender: a busca por um entendimento entre "mundos" diferentes. A violência está vinculada, por exemplo, ao mundo do adulto:

Dona Doninha:

(entra com uma vara na mão) Até que enfim te apanho, Macaco Simão! Agora você vai aprender como arde uma urtiga. Toma, toma, toma. (Ela bate e Simão pula, grita e procura safar-se). (Ibid., p. 8) 
O Dono do Circo

(batendo-lhe outra vez) Toma! Assim você aprende a respeitar o dono do Circo Rataplan. (continua a bater no macaco que se defende como pode). (Ibid., p. 32)

Isto nada mais é que personificar o mal, a crueldade, unicamente no adulto, que age e pensa de forma racional e pragmática, como o Comprador, em A Invasão das Tiriricas: "Na minha terra [cidade] ninguém perde tempo descansando fora de hora" (Ibid., p. 17). O que expõe a dicotomia entre o campo e a cidade e aponta o fator externo desequilibrando o interno, onde os personagens citadinos e adultos são a representação do mal, do antagonismo. Por outro lado, a Estrelinha Cadente e o Macaco Simão são os "filhotes" que possuem sentimentos bons, distantes desta realidade. Porém, o autor não deixa espaço a interpretações psicológicas de tais ações, pois neste mundo quem não se comporta, há de corrigir-se por bem ou por mal, e as famosas palmadas não são tratadas como um ato de violência extrema contra a criança. Elas são um exemplo de reação pedagógica a uma ação de molecagem, vide a surra da velha no macaco, logo na primeira peça.

O personagem de Dona Doninha é a figura maternal e anciã, que materializa na sua rotina e organização um mundo seguro, feliz e em harmonia. Se, na primeira história, age como educadora, dando "corretivos" no macaco-moleque até "negociar" uma nova relação, nas outras duas sequências atua como o adulto que protege e ampara a criança-filhote contra os males externos. E Simão é o macaquinho-netinho, meio preguiçoso, hedonista, que gosta de ir às festas e se divertir; de dormir até o meio-dia, pois vive com sono. Ele é como uma criança comum, um menino esperto, "tinhoso" e encrenqueiro que faz "arte"; que aprende a respeitar o adulto, entretanto, sem perder seu senso questionador, provocador e lúdico, o que lhe acarreta sempre novas confusões.

Há outros personagens, mas de pura função narrativa, estereotipados e com pouca consistência dramática, ou seja, meras tipologias que correspondem ao seu estado social/natural, como o Vizinho Catatão, as Tiriricas e a Lua, sendo que esta última compõe uma cena de fantasia, lúdica e cheia de lirismo.

$\mathrm{O}$ contexto espaço-temporal da trilogia é predominantemente rural, próximo à natureza, já o cenário é o sítio de Dona Doninha nas duas partes iniciais, todavia, na terceira, os ambientes deslocam-se para a floresta e o picadeiro do circo. O tempo da ação é condensado, relativamente curto e sucessivo, desenvolvendo-se com a duração média de um dia, o que facilita a apreensão da narrativa, vide em $A$ Invasão das Tiriricas, as didascálias que introduzem os quadros: “1. O pátio de Dona Doninha (manhã). Ao centro do terreiro, o 
Poço. [...] 3. É noite e os grilos cantam. O Poço, apoiado na sua borda, examina o céu com uma luneta. [...] 6. É de manhã. [...] 7. Horas depois" (Ibid., p. 17-26).

A questão da linguagem e sua adequação é um dos elementos centrais na composição da obra infanto-juvenil de Ivo Bender. É justamente neste ponto que o trabalho mostra toda a sua qualidade, riqueza e força literária/dramatúrgica. A simplicidade e o despojamento caracterizam a trilogia, além de um primoroso trabalho com o ritmo dos diálogos, a sonoridade das palavras e a criatividade nos versos e provérbios populares. A proximidade ao uso cotidiano, popular e coloquial da linguagem demonstra uma sensibilidade à recepção de seu público, resultando em uma maior identificação da criança e do jovem com as personagens e, por consequência, com as histórias em si. Porém, há um tratamento diferenciado em cada parte da trilogia. Em O Macaco e a Velha, o lúdico predomina, sendo isso visível na relação, por exemplo, de Dona Doninha com a natureza: "O galo cantou, o sol já vem nascendo e é hora de começar o dia. (Alegremente) Bom dia, sol. Bom dia, galo. Bom dia, dia!" (Ibid., p. 5).

N'A Invasão das Tiriricas, o realismo dá o tom do discurso, objetivando-o:

O Comprador:

Essa velha Dona Doninha pensa que pode se ver livre de mim. Trouxe este saco de sementes de tiririca-tinhosa-gigante, a planta que ataca quem não me obedece. Deixo cair uns grãozinhos em roda deste poço dorminhoco e logo, logo, as coisas vão mudar. As tiriricas não vão deixar ninguém chegar junto do poço. Só eu. (Ibid., p. 23)

Com A Estrelinha Cadente, o lírico, embora posto de forma simples, está presente em sua composição, vide o tom da fala de Áurea - meio melancólico, pensativo, sonhador que se utiliza de uma prosa poética marcada pelo uso de sintagmas de curta extensão e de rima, como "pensar" e "encontrar": "Ah, se vocês soubessem o que passei naquele circo! Mas nem é bom pensar. Acho que ali, atrás daquela moita, ninguém, nem mesmo aquele dono de circo, consegue me encontrar" (Ibid., p. 31).

Os diálogos são curtos, ágeis, humorados e com um mínimo de adjetivação, o que impulsionam a ação dramática, concentrando na cena o desenvolvimento da narrativa e evitando as anacronias, como prolepses. Outras figuras de linguagem estão presentes, como assonâncias (Boneco para Simão: "Não dou uma, nem duas, nem três nem coisa nenhuma!") (Ibid., p. 8), pleonasmos (Doninha para o Poço: “Alô, meu poço! Como vai essa água gelada?") (Ibid., p. 10) e hipérboles (Simão para Doninha: "Isso é pra não se meter com Simão, o gorilão das bananeiras") (Ibid., p. 11). O uso de subterfúgios ou subjetividades, vide as dificuldades das crianças em compreender possíveis abstrações, dão lugar à clareza de um Anuário de Literatura, vol. 14, n. 1, 2009, p. 56 
discurso objetivo:

Simão:

(Acorda, boceja e espreguiça-se) Sonhei que tinha alguém cantando por aí... Credo! Quem é esse sujeito preto parado aí feito um boneco?

O Boneco:

Sou o protetor das bananeiras de Dona Doninha. De hoje em diante, para roubar, você vai ter que me enfrentar. (Ibid., p. 7-8)

Os comentários dos personagens dirigidos ao espectador/leitor não incorrem em artifícios dramáticos, pois não objetivam a participação e adesão forçada do público, nem buscam o humor fácil, antes lúdico. Há elementos que agregam à ação dramática uma qualidade de comunicação e interação espontânea, como a surpresa, o suspense ou a comoção. Como exemplo, segue a triste canção de Áurea, em A Estrelinha Cadente: "Se eu encontrasse alguém/Que pudesse me ajudar/ Nesta terra de ninguém,/ Eu lhe agradeceria/ Com um fio de luar" (Ibid., p. 35).

As canções representam um capítulo à parte dentro da estrutura dramática da trilogia, visto que sempre se colocam a favor do desenvolvimento da ação, ora caracterizando personagens, situações ou estados emocionais, ora introduzindo uma atmosfera lúdica de pura fruição. A estrutura lírica que se apresenta é formada sempre por redondilhas maiores, característica das cantigas infantis. Na última citação, por exemplo, há a presença tanto de rimas internas (encontrasse/pudesse) quanto externas (alguém/ninguém, ajudar/luar) que ajudam a manter o ritmo e a estabelecer a melodia da canção - recursos que auxiliam a sustentar a atenção dos espectadores/leitores. O uso da metáfora 'como um fio de luar' não só faz parte do universo conhecido do personagem como também do imaginário popular, de uma ligação entre o real e o mágico.

Compostas por Léo Ferlauto, a música serve como um elemento de motivação de interesse da criança. Em $O$ Macaco e a Velha, um dos momentos em que ela é significativa é o de apresentação de um dos personagens:

O Boneco de Piche:

[...] Eu sou o boneco de piche

Pretinho como carvão,

Fui criado por minha dona

Para prender um ladrão.

Macaco que rouba banana

Não merece perdão:

Eu prendo na mesma hora

Anuário de Literatura, vol. 14, n. 1, 2009, p. 57 
- grudado na minha mão!

Eu sou o sentinela,

O guarda do bananal,

Só tenho um grande problema:

Não posso sair do quintal. (Ibid., p. 7)

Além da finalidade acima, nessas peças, a música também é usada para fazer a descrição do cotidiano dos personagens em seu universo, que é rural, próximo à natureza. Serve de ilustração uma das falas de D. Doninha: “Água de poço, bem fresquinha,/ Gostosa de se beber,/ Boto um pouco na quartinha,/ Boto o resto pra ferver. / E faço um feijão gostoso/ E uma sopa de um só osso, / Em tudo entra um pouco/ Desta água do meu poço” (Ibid., p. 9$10)$.

Por fim, como desfecho das peças, em que a resolução dos conflitos deflagrados transmite a ideia de conservar ou alterar a ordem anteriormente transtornada, surge um resumo de onde se retira uma lição de cada narrativa. No entanto, salienta-se que essa síntese funciona, também, como encerramento de um ciclo, onde a canção se constitui em um poderoso instrumento lúdico do espetacular:

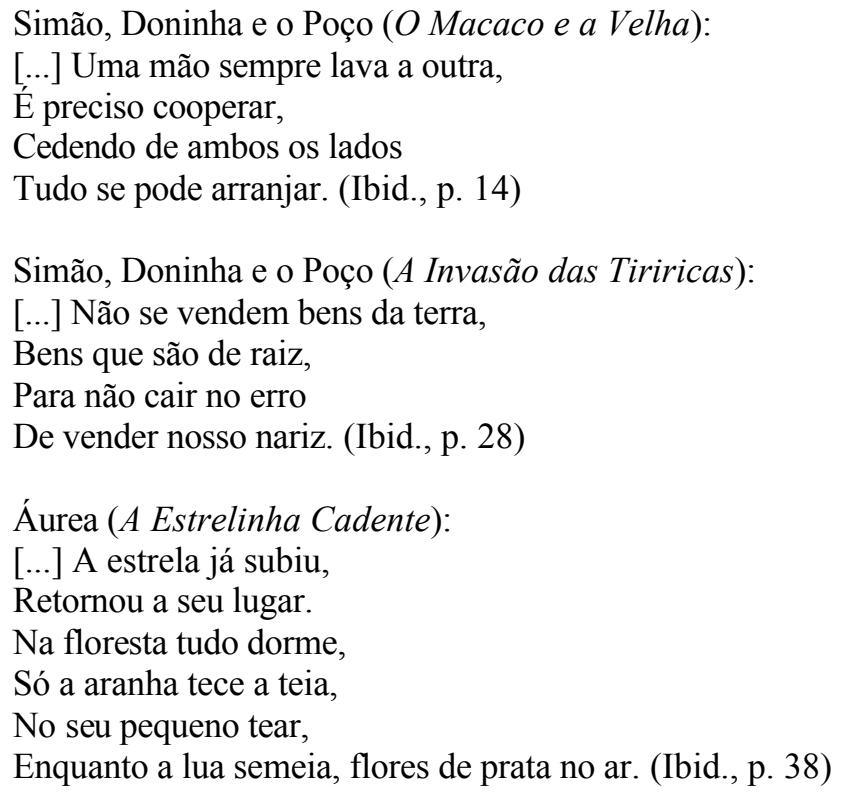

Ao realizar uma leitura sob a abordagem qualitativa de Pupo (1991), utilizando as noções de didatismo, maniqueísmo e estereótipo como aspectos negativos da linguagem, verifica-se que o tríptico incorre com algumas ações, situações e caracterizações dentro da classificação, embora inove por outro lado com inventividade e originalidade ao trabalhar com estes mesmos aspectos a seu favor. 
O didatismo se configura em duas situações básicas: uma que adianta o que vai acontecer ou o que aconteceu em cena, a exposição, e outra que encerra a peça com uma lição de moral construtiva. São momentos em que a verbalização substitui a ação, porém, não há tentativa de manipular ou provocar emoções nas crianças, e sim, alimentar a tensão dos conflitos, como suspense anunciado, instigando ainda mais a imaginação do público. O maniqueísmo está presente em $A$ Invasão das Tiriricas e $A$ Estrelinha Cadente de forma explícita, o que é contraditório com a própria construção dos personagens n'O Macaco e a Velha, onde a ambivalência de sentimentos e comportamentos é uma característica intrínseca dos protagonistas. Nas duas últimas partes, o Bem e o Mal enquadram o conflito em dois polos opostos: os elementos estranhos (o Comprador de Água e o Dono do Circo) contra os familiares (Doninha, Simão, Poço, etc.); o urbano contra o rural; o adulto contra a criança.

A noção maniqueísta posta em ações, e não apenas no discurso, como é o caso da trilogia, não é condenável por psicólogos e pedagogos, visto que, facilita a compreensão da trama pela criança ao simplificar o conflito principal e não a construção dos personagens, ou seja, não há uma perda da qualidade da obra, ao contrário. Todavia, este mesmo conceito traz consigo toda a força de sua dialética ao permitir a veiculação de preceitos éticos e morais, normas de comportamento, contribuindo ainda mais ao didatismo que diminui a função simbólica do discurso e, por fim, à estereotipia, visto que a concepção dos personagens de índole má é banal, estática e padronizada. Quanto à subjetividade, não há evolução dos mesmos, e sim, a ausência de dúvidas, contradições e/ou autocrítica, salvo as exceções já apontadas.

Ao encerrar as considerações analíticas, interpretativas e críticas da linguagem e dos recursos literários/dramáticos d'O Macaco e a Velha, torna-se possível cotejar a obra e seu contexto histórico e concluir que a inovação ou conservação são relativas quando adotadas as perspectivas de adequação de linguagem (Camarotti, 2005) e seus usos (Pupo, 1991). A obra infanto-juvenil de Ivo Bender talvez reflita os mesmos paradigmas de sua época: o transitório entre o artístico e o educativo.

\section{Das ilações de uma dramaturgia para jovens e crianças.}

Brasil, anos 2000, nos palcos do país é (re)encenada, repetidamente, há mais de três décadas, o paradoxo de uma produção discrepante, entre o eterno-retorno da função pedagógica e a mitigada concepção da pura fruição artística. Aliás, aquela incorporou esta, e 
aprendeu os maneirismos estéticos para continuar reproduzindo disfarçadamente, sob o invólucro do espetacular, sua mônada didática, moralizante e reducionista.

Sob o prisma histórico, o avanço dos anos 70, em questões de linguagem literária e cênica, não encontrou uma continuidade relevante, apesar de algumas "ilhas" de resistência no cenário teatral contemporâneo. O que era sopro de um recomeço, logo se arrefeceu ou marginalizou-se. As premissas estéticas, que elevaram o período ao reconhecimento de uma mudança de paradigmas, foram cooptadas pela produção "comercial" e educativa. O caráter pedagógico das relações entre adultos e crianças prevalece sobre a noção de que a arte teatral, por sua natureza, pode contribuir de forma mais ampla à dimensão cognitiva do ser humano pelo simples fato de que a arte também produz conhecimento. É a reflexão que (re)surge: a desigualdade de poderes gera a deformação da linguagem, a fim de servir a determinados axiomas instituídos, ora artísticos, ora pedagógicos, sempre intermitentes. E os autores, encenadores e educadores, de alguma forma, veem-se compelidos a '(re)elaborar' e/ou '(re)tomar' a questão a cada nova criação.

Em O Macaco e a Velha, Ivo Bender prefigura tal panorama paradoxal, uma vez que compõe a obra entre os princípios estéticos da nova e velha dramaturgia. É um ponto de convergência entre a tradição pedagógica das décadas que o precedem e o artístico anunciado como promessa de uma transformação futura. A trilogia é um exemplo de que é possível um diálogo entre heranças discrepantes, sem sacrificar a qualidade do literário, o estilo do discurso e o artístico-lúdico.

Mais do que inovador, ele se mostra renovador. O tríptico apresenta um nível de qualidade, porquanto de criação artística, acima da produção dramatúrgica de então, já que, a construção da ação dramática é fundada sobre uma estrutura discursiva una, coerente e sólida, ao contrário do que costumeiramente se escrevia, como dramas fragmentados, contraditórios e precários, de uma verbalização excessiva, denunciando sua inconsistência. Repete-se a máxima: teatro é mais ação do que verbo. Apesar de uma estrutura dramática simples, a trilogia d'O Macaco e a Velha vislumbra uma experiência criativa, original e renovadora da linguagem do teatro infanto-juvenil, dentro do contexto dos anos 70. A primazia pelo respeito à individualidade, imaginação e inteligência da criança é um dos grandes trunfos das peças, assim como convidam a participação do público pela adesão voluntária, não forçada. $\mathrm{O}$ domínio estético é evidente e se comprova com a adequação dessa linguagem sempre próxima a dialogar com o universo da criança; consciente do poder que contém, a obra amortece o impacto das desigualdades que implicam a relação produtor-adulto/receptor - criança. 
Com a variação temática, retirada do imaginário popular, recupera o lúdico, o imagético e o simbólico; resgata a afetividade e o lirismo contra o racionalismo operante; e, coloca o cotidiano rural como fator de agregação de valores à identidade de uma dramaturgia nacional. O universo mágico convive harmoniosamente com o real, permitindo a representação externa dos processos internos sofridos pelas crianças e enriquecendo a composição dos personagens e a identificação do público. As personagens antropomorfizadas são consistentes pelas suas ações, conflitos internos e externos e vontades, o que empresta agilidade e concisão à história, sempre questionadora da manutenção dos preconceitos e preceitos da ordem social. A construção de sentido e interpretação de seu discurso vislumbram retorquir as relações humanas e o lugar-comum das coisas, apresentando possibilidades e alternativas diversas das comumente representadas.

Apesar de renovador, ele também se mostra conservador. Visto que opera uma diluição do discurso moral, em pequenas mensagens de cunho ético-pedagógico, nas canções que finalizam cada parte da obra. O autor não realiza um desligamento da tradição moralizante da dramaturgia, pois reconhece o poder e as responsabilidades a ele vinculadas na criação literária para crianças e jovens, e por isso escreve fábulas antiautoritárias, solidárias e políticas, no sentido puro da expressão. Acrescenta-se a isto, o maniqueísmo e o estereótipo de alguns personagens, que até funcionam um pouco como ponto de esvaziamento qualitativo dos textos. Todavia, como a carpintaria do discurso dramático está bem urdida sobre a ação e os conflitos, e não sobre a simples verbalização da dicotomia entre o Bem e o Mal, o texto consegue trabalhar a seu favor tais fatores negativos da linguagem que tanto marcaram a época.

O Macaco e a Velha é a expressão de um processo dialético, histórico e estético: a confluência de um paradigma de função pedagógica a outro de função artística, sem alterar a função social do teatro. Na verdade, é uma obra que revela que o decurso de sua concepção é contaminado em sua episteme pelo que atrai e repele, ou seja, a transitoriedade estética e a impureza discursiva são inerentes à complexidade desta composição, que não deixa dúvidas sobre sua qualidade e sua influência na história de um teatro para crianças e adolescentes.

\section{REFERÊNCIAS}

ÁRIES, Philippe. História social da criança e da família. Rio de Janeiro, 1978. BERTHOLD, Margot. História Mundial do Teatro. São Paulo: Perspectiva, 2006. 
BENDER, Ivo Cláudio. O Macaco e a Velha: uma trilogia para crianças. Porto Alegre: Mercado Aberto, 1985.

. Teatro escolhido. Porto Alegre: Bels/IEL, 1975.

BORDINI, Maria da Glória. Poesia infantil. São Paulo: Ática, 1991.

CAMAROTTI, Marco. A linguagem no teatro infantil. $3^{\text {a }}$ ed. Recife: Ed. Universitária da UFPE, 2005.

INSTITUTO ESTADUAL DO LIVRO. Ivo Bender. Porto Alegre: IEL, 1984. 24 p. 17.

LOMARDO, Fernando. O que é teatro infantil? São Paulo: Brasiliense, 1994.

MAGALHÃES, Lígia Cademartori; ZILBERMAN, Regina. Literatura infantil: autoritarismo e emancipação. São Paulo: Ática, 1982.

MARCHI, Diana Maria. A literatura infantil gaúcha: uma história possível. Porto Alegre: UFRGS, 2000.

PALLOTTINI, Renata. Dramaturgia: a construção do personagem. São Paulo: Ática, 1995.

PUPO, Maria Lúcia de Souza B. No reino da desigualdade. São Paulo: Perspectiva, 1991.

SANTOS, Vera Lucia Bertoni dos. Criança, teatro e dramaturgia. In: JACOBY, Sissa (org). A criança e a produção cultural: do brinquedo à literatura. Porto Alegre: Mercado Aberto, 2003. 